\title{
Hubungan Intensitas Polusi Isolator Jaringan Distribusi di Sumatera Utara dengan Jarak Lokasi Isolator dari Pantai
}

\author{
Bonggas L. Tobing dan Mustafriend Lubis \\ Laboratorium Teknik Tegangan Tinggi \\ Departemen Teknik Elektro, Fakultas Teknik USU \\ Jl. Tri Dharma, Medan 20155 \\ E-mail: botobing@yahoo.com
}

\begin{abstract}
ABSTRAK
Paper ini melaporkan hasil penelitian tentang tingkat intensitas polusi pada isolator jaringan distribusi hantaran udara $20 \mathrm{kV}$ di Sumatera Utara. Ditemukan bahwa tingkat intensitas polusi isolator jaringan distribusi hantaran udara $20 \mathrm{kV}$ di Sumatera Utara termasuk kategori ringan. Intensitas polusi pada suatu isolator semakin rendah jika isolator semakin jauh dari pantai. Setelah jarak isolator dari pantai mencapai kurang lebih $40 \mathrm{~km}$, intensitas polusi pada isolator turun $\pm 50 \%$ dari intensitas polusi isolator yang terdekat ke pantai. Pada jarak di antara 40 - $80 \mathrm{~km}$ dari pantai, intensitas polusi isolator hampir konstan. Artinya, kandungan garam yang dibawa angin laut tidak berpengaruh lagi terhadap polutan isolator jika jarak isolator dari pantai lebih dari $40 \mathrm{~km}$.
\end{abstract}

Kata kunci: distribusi, isolator, polusi, ESDD.

\section{ABSTRACT}

This paper reports the result of research about the pollution intensity of the insulator of $20 \mathrm{kV}$ electrical distribution network in North Sumatera. It has investigated that the pollution intensity of the insulator of $20 \mathrm{kV}$ electrical distribution network in North Sumatera is in low category. The pollution intensity of an insulator is decrease if the distance of mentioned insulator more far away from the seashore. If the distance of insulator from seashore about $40 \mathrm{~km}$, the decreasing of pollution intensity reach to $\pm 50 \%$ of pollution intensity of insulator that close to the seashore. The pollution intensity of insulator almost constant if the distance of insulator from seashore is between $40 \mathrm{~km}$ to $80 \mathrm{~km}$. It means that the salt contained on air which is blow from the sea is not influence on insulator pollution if the distance of mentioned insulator from seashore more than 40 $\mathrm{km}$

Keywords: distribution, insulator, pollution, ESDD.

\section{PENDAHULUAN}

Salah satu komponen utama dari jaringan distribusi tenaga listrik hantaran udara adalah isolator. Isolator berfungsi mengisolir konduktor jaringan yang bertegangan dengan tiang penyangga konduktor agar arus listrik tidak mengalir dari konduktor jaringan ke tanah. Ada beberapa hal yang dapat membuat isolator gagal melaksanakan fungsinya, salah satu di antaranya adalah peristiwa lewat-denyar. Peristiwa lewatdenyar pada suatu isolator dapat mengakibatkan terjadinya hubung singkat ke tanah dan pada akhirnya dapat menimbulkan terputusnya pengiriman energi listrik kepada konsumen. Terjadinya lewat-denyar pada suatu isolator tergantung kepada: kekuatan isolasi isolator; tegangan yang dipikul isolator; temperatur, tekanan dan kelembaban udara di sekitar isolator; dan konduktivitas polutan yang menempel pada isolator tersebut.

Catatan: Diskusi untuk makalah ini diterima sebelum tanggal 1 Desembe 2007. Diskusi yang layak muat akan diterbitkan pada Jurnal Teknik Elektro volume 8, nomor 1, Maret 2008.
Polutan yang menempel pada suatu isolator berasal dari polutan yang terdapat pada udara di sekitar isolator tersebut. Polutan yang terbawa udara dapat menempel pada permukaan isolator dan berangsurangsur membentuk suatu lapisan yang tipis pada permukaan isolator. Polutan yang paling berpengaruh terhadap lewat denyar isolator adalah unsur garam. Unsur garam yang mencemari suatu isolator sebagian besar berasal dari angin laut. Angin laut dapat mengendapkan lapisan garam di permukaan isolator yang terpasang di daerah-daerah yang berdekatan dengan pantai. Lapisan garam ini bersifat konduktif terutama pada keadaan cuaca lembab, berkabut atau pada saat hujan gerimis [1]. Jika cuaca seperti ini terjadi maka akan mengalir arus bocor dari konduktor jaringan ke tanah melalui lapisan garam yang menempel di permukaan isolator dan tiang penyangga. Adanya arus bocor ini akan memicu terjadinya peluahan parsial pada permukaan isolator. Peluahan parsial ini merupakan cikal-bakal dari terjadinya peristiwa lewat-denyar pada isolator [2,3]. Oleh karena itu, dalam perencanaan isolator jaringan baru 
maupun dalam penyempurnaan isolator jaringan yang sudah terpasang perlu adanya informasi tentang tingkat intensitas polusi di daerah lintasan jaringan tersebut. Informasi ini merupakan pedoman bagi perencana untuk menentukan jenis, jumlah dan jarak rambat isolator yang akan digunakan pada jaringan yang direncanakan itu $[4,5]$.

Oleh karena polutan yang paling berpengaruh terhadap kejadian lewat denyar pada suatu isolator adalah konduktivitas lapisan garam yang mencemari isolator dan garam tersebut sebagian besar terbawa oleh angin laut, maka konduktivitas polutan yang menempel pada suatu isolator tergantung pada jarak isolator tersebut dari pantai. Dengan mengambil contoh kasus di Sumatera Utara, akan ditunjukkan bahwa konduktivitas polutan yang menempel pada suatu isolator dipengaruhi jarak lokasi isolator dari pantai.

\section{TEORI}

Kebutuhan energi listrik di Sumatera Utara disediakan oleh PT PLN (Persero) Distribusi Wilayah II Sumatera Utara. Energi listrik didistribusikan kepada konsumen sebagian besar melalui jaringan hantaran udara $20 \mathrm{kV}$. Sebelumnya telah dijelaskan bahwa salah satu komponen utama jaringan hantaran udara adalah isolator. Isolator ini terpasang pada ruang terbuka, sehingga beberapa tahun sejak pemasangannya, pada permukaan isolator menempel polutan yang bersifat permanen. Intensitas polutan pada isolator tersebut tergantung kepada tingkat pencemaran udara dan unsur polutan yang terkandung dalam udara di sekitar isolator. Tingkat pencemaran dan kandungan polutan di sekitar suatu isolator tergantung kepada sumber polutan dan jarak isolator dari sumber polutan tersebut.

Daerah Sumatera Utara berbatasan dengan Selat Malaka dan lautan Hindia, maka uap air laut di selat Malaka dan lautan Hindia merupakan salah satu sumber polutan bagi isolator-isolator yang terpasang di Sumatera Utara. Di samping itu, udara di Sumatra Utara juga membawa polutan yang bersumber dari limbah industri, limbah pemukiman dan limbah perkebunan. Limbah industri dan limbah pemukiman hanya ditemukan di kota Medan dan sekitarnya.

Limbah perkebunan yang dapat mencemari suatu isolator di Sumatera Utara berasal dari asap pabrik kelapa sawit dan asap pembakaran lahan perkebunan. Telah dijelaskan bahwa isolator digunakan dalam rangka penyaluran energi listrik kepada konsumen. Oleh karena itu, populasi isolator lebih banyak di daerah pemukiman. Sedang pabrik kelapa sawit tersebar di beberapa tempat dan jauh dari pemukiman sehingga asapnya tidak mencemari banyak isolator. Dengan demikian sumber polutan terbesar bagi isolator jaringan distribusi di Sumatera Utara adalah angin laut. Jika sumber polutan utama adalah angin laut, maka intensitas polutan yang menempel pada suatu isolator tergantung pada jarak isolator tersebut dari tepi laut. Untuk lebih jelasnya, perhatikan peta Sumatera Utara pada Gambar 1.

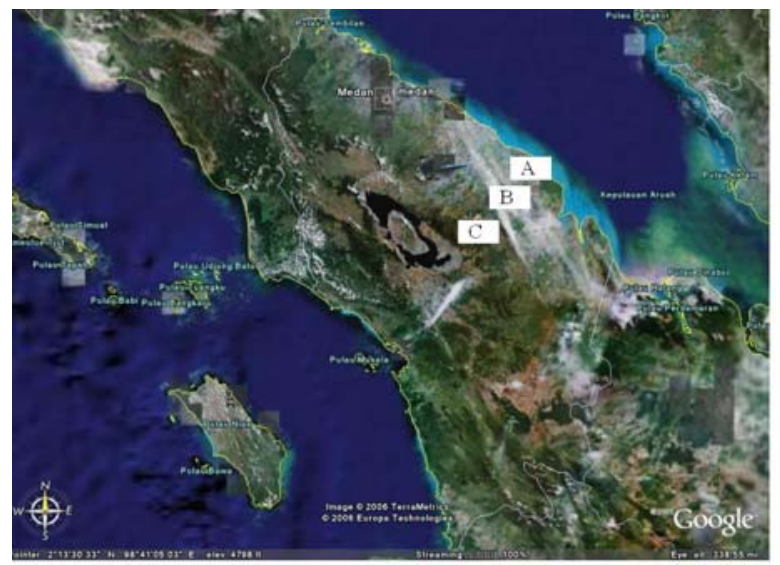

Gambar 1. Peta Sumatera Utara

Jika arah angin laut yang paling sering terjadi dimisalkan seperti arah panah, maka intensitas polutan pada isolator yang berada di kawasan A lebih berat dibandingkan dengan intensitas polutan isolator di kawasan $\mathrm{B}$ dan $\mathrm{C}$; sedang intensitas polutan pada isolator yang berada di kawasan B lebih berat dibandingkan dengan intensitas polutan isolator di kawasan C.

Seandainya arah angin laut yang paling sering terjadi tidak seperti yang ditunjukkan pada Gambar 1, maka intensitas polutan pada isolator yang berada di kawasan A tetap lebih berat dibandingkan dengan intensitas polutan isolator di kawasan B dan C; sedang intensitas polutan pada isolator yang berada di kawasan $\mathrm{B}$ tetap lebih berat dibandingkan dengan intensitas polutan isolator di kawasan $\mathrm{C}$.

Penelitian ini bertujuan untuk memperoleh hubungan antara intensitas polutan isolator dengan jarak isolator dari garis pantai, sehingga intensitas polutan isolator pada suatu kawasan di daerah Sumatera Utara dapat diperkirakan dengan mengetahui jarak daerah itu dari garis pantai. Perkiraan ini dapat dipergunakan sebagai bahan pertimbangan dalam merancang isolator jaringan distribusi hantaran udara di Sumatera Utara dan daerah lain yang kondisi geografisnya hampir sama dengan Sumatera Utara. Hubungan dimaksud dapat diperoleh dengan mengukur intensitas polutan 
yang menempel pada isolator jaringan hantaran udara $20 \mathrm{kV}$ milik PT PLN (Persero) Wilayah II Sumatera Utara yang telah terpasang di sekitar kawasan A, B dan $\mathrm{C}$ yang telah ditunjukkan pada Gambar 1 .

\section{METODOLOGI PENGUKURAN INTENSITAS POLUTAN ISOLATOR}

Sampel untuk pengukuran ESDD adalah isolator jaringan hantaran udara $20 \mathrm{kV}$ milik PT PLN (Persero) Wilayah II yang menyebar di Sumatera Utara. Ada tiga jenis isolator yang digunakan PT PLN (Persero) Wilayah II di Sumatera Utara, yaitu jenis pin, jenis pin-post dan jenis piring. Isolator yang terbanyak digunakan adalah jenis pin, sehingga sampel isolator yang dipilih adalah jenis pin seperti yang ditunjukkan pada Gambar 2. Semua sampel diambil dari jaringan yang umur pemasangannya hampir sama, yaitu 11-12 tahun.

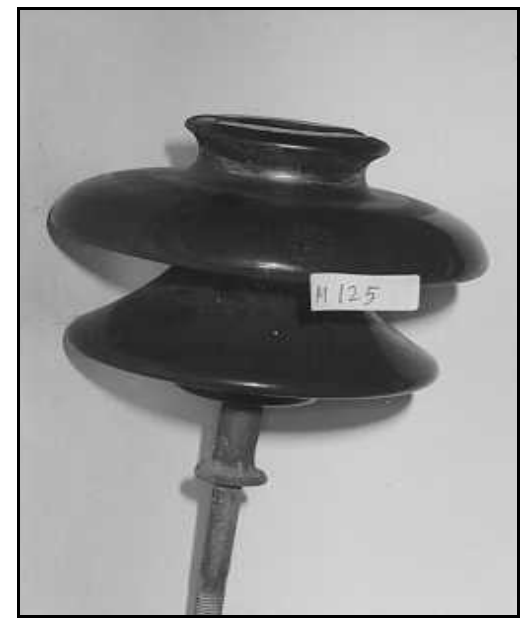

Gambar 2. Isolator Jenis Pin

Sumatera Utara dibelah dua oleh pegunungan Bukit Barisan. Kawasan yang berbatasan dengan samudera Hindia disebut kawasan Pantai Barat, sedang kawasan yang berbatasan dengan Selat Malaka disebut kawasan Pantai Timur. Kawasan Pantai Barat berupa dataran tinggi sedang kawasan Pantai Timur berupa dataran rendah. Populasi isolator di kawasan Pantai Barat lebih sedikit dibandingkan dengan populasi isolator di kawasan Pantai Timur. Oleh karena itu, kawasan yang dipilih menjadi lokasi pengambilan sampel isolator adalah kawasan Pantai Timur.

Jumlah lokasi pengambilan sampel ditetapkan di empatbelas lokasi. Banyaknya isolator yang diambil dari setiap daerah pengambilan sampel adalah 5 unit.

Agar polutan pada isolator benar-benar hanya yang terbawa angin laut, maka isolator di ambil dari daerah yang bebas polusi industri dan perkotaan. Lokasi pengambilan sampel berurut mulai dari yang terdekat ke pantai hingga daerah yang terjauh dari pantai. Ketinggian suatu lokasi pengambilan sampel harus sama atau lebih tinggi dari lokasi pengambilan sampel sebelumnya, agar tidak ada sampel yang terlindung dari terpaan angin laut. Jarak sampel isolator dari pantai ditetapkan sama dengan jarak terpendek dari lokasi pengambilan sampel ke pinggir pantai. Jarak lokasi isolator dari pantai dan ketinggian daerah pengambilan isolator diperoleh dari Peta Rupa bumi Indonesia, skala 1:50.000, yang diterbitkan Bakosurtanal, tahun 1982.

Tingkat intensitas polusi pada suatu isolator dinyatakan dengan mengukur daya hantar listrik (konduktivitas) larutan polutan dalam air murni. Kemudian dicari konsentrasi larutan garam dalam air murni yang pada suhu dan volume air murni yang sama mempunyai konduktivitas yang sama dengan hasil pengukuran konduktivitas larutan polutan. Karena konduktivitas larutan polutan disetarakan dengan konduktivitas larutan garam dalam air, maka metode pengukuran ini disebut metode "Equivalent Salt Deposit Density" (ESDD). Pengukuran tingkat intensitas polutan yang mencemari suatu isolator dengan metode ini disebut metode ESDD $[6,7,8]$.

Prosedur pengukuran tingkat intensitas polutan dengan metode ESDD adalah sebagai berikut:

Suatu gelas ukur dibersihkan dengan air destilasi. Setelah bersih, gelas ukur diisi dengan $500 \mathrm{ml}$ air destilasi yang akan digunakan mencuci isolator (selanjutnya disebut air pencuci). Ke dalam air pencuci dimasukkan empat carik kain kasa steril ukuran $16 \mathrm{~cm} \times 16 \mathrm{~cm}$ dan satu sikat plastik yang sudah terlebih dahulu dibersihkan dengan air destilasi. Gelas ukur yang berisi air pencuci ditempatkan dalam ruangan pendingin hingga temperatur air pencuci mencapai $20^{\circ} \mathrm{C}$. Air pencuci diaduk agar temperaturnya merata. Saat temperatur air pencuci mencapai $20^{\circ}$ $\mathrm{C}$, konduktivitas air pencuci diukur dengan alat pengukur konduktivitas. Selama pengukuran, kain kasa dan sikat plastik tetap berada dalam gelas ukur. Alat ukur yang digunakan adalah konduktivitimeter merek HANNA, Type HI 9032. Alat ukur ini dikalibrasi terlebih dahulu dengan "buffer" yang sesuai dengan kondukvitas air pencuci.

Konduktivitas air pencuci disetarakan dengan konduktivitas konsentrasi larutan garam $\mathrm{NaCl}$ dalam air murni. Kesetaraannya ditentukan dengan mencari konsentrasi garam dalam larutan air murni yang konduktivitasnya sama dengan konduktivitas air pencuci. Konsentrasi garam dalam suatu larutan air 
murni pada temperatur $20^{\circ} \mathrm{C}$, dapat ditentukan dari persamaan di bawah ini:

$$
\begin{aligned}
\mathrm{D} & =\frac{\left(5.7 \times 10^{-4} x \sigma_{20}\right)^{1.03}}{10} \mathrm{ESDD} \\
& =0,0204-0,00356 \mathrm{x} \ln
\end{aligned}
$$

di mana:

$\mathrm{D}=$ Konsentrasi garam (\%)

$\sigma_{20}=$ Konduktivitas larutan pada temperatur $20^{\circ} \mathrm{C}$ $(\mu \mathrm{S} / \mathrm{cm})$

Misalkan konduktivitas larutan pencuci setara dengan konduktivitas larutan garam yang konsentrasi garamnya adalah $\mathrm{D}_{1}$.

Kemudian satu baskom yang terbuat dari plastik dibersihkan dengan air destilasi. Isolator sampel dicuci dalam baskom plastik itu dengan air pencuci. Air pencuci disisakan sebagian untuk pencucian akhir. Sikat plastik digunakan untuk memisahkan polutan dari permukaan isolator. Selama pencucian, dijaga agar bahagian logam isolator tidak ikut tercuci. Dua helai kain kasa digunakan untuk menyerap semua polutan dari permukaan isolator sampel. Setelah isolator bersih, air cucian dimasukkan kembali ke dalam gelas ukur. Kain kasa yang dua helai lagi digunakan untuk menyerap larutan polutan dari bejana pencucian dan memasukkannya ke dalam gelas ukur. Semua kain kasa dan sikat plastik dimasukkan kembali ke dalam gelas ukur. Gelas ukur yang berisi larutan polutan ditempatkan dalam ruangan pendingin hingga temperatur larutan mencapai $20^{\circ} \quad$ C. Saat temperatur larutan polutan mencapai $20^{\circ} \mathrm{C}$, konduktivitas larutan polutan diukur dengan alat pengukur konduktivitas yang sama dengan pengukur konduktivitas air pencuci. Konduktivitas larutan polutan disetarakan dengan konduktivitas konsentrasi larutan garam $\mathrm{NaCl}$ dalam air murni dengan menggunakan persamaan (1). Misalkan hasilnya adalah $\mathrm{D}_{2}$.

Selanjutnya dihitung luas permukaan isolator, yaitu luas semua permukaan keramik yang membentuk isolator tersebut. Dalam hal ini, luas bahagian logam isolator tidak ikut diukur. Seperti terlihat pada Gambar 2, isolator sampel dibentuk oleh empat sirip yang bentuknya mirip dengan kerucut terpotong, di mana salah satu di antaranya yaitu sirip paling atas berbentuk kerucut terpotong terbalik. Secara pendekatan, luas permukaan dalam dan permukaan luar sirip-sirip tersebut dapat dihitung dengan menggunakan rumus luas permukaan kerucut terpotong. Yang dimaksud dengan luas permukaan isolator adalah jumlah luas permukaan dalam dan luas permukaan luar semua sirip yang membentuk isolator tersebut.

ESDD satu unit isolator sampel dihitung dengan rumus (2) di bawah ini:

$\mathrm{W}=10 \times \mathrm{V} \times\left(\mathrm{D}_{2}-\mathrm{D}_{1}\right) / \mathrm{S}$

di mana:

$\mathrm{W}=\mathrm{ESDD}\left(\mathrm{mg} / \mathrm{cm}^{2}\right)$

$\mathrm{V}=$ Volume air destilasi dalam gelas ukur (cc)

$\mathrm{D}_{1}=$ Konsentrasi kesetaraan garam dalam air pencuci $(\%)$

$\mathrm{D}_{2}=$ Konsentrasi kesetaraan garam dalam larutan polutan (\%)

$\mathrm{S}=$ Luas permukaan isolator $\left(\mathrm{cm}^{2}\right)$

Selama pengukuran, laboran memakai sarung tangan karet steril agar keringat tidak mencemari larutan yang digunakan selama pengukuran.

\section{HASIL PENGUKURAN}

Telah disebutkan sebelumnya bahwa jumlah lokasi pengambilan sampel ditetapkan di empatbelas lokasi. Banyaknya isolator yang diambil dari setiap daerah pengambilan sampel adalah 5 unit. Nilai ESDD pada suatu lokasi ditetapkan dengan menghitung nilai ratarata ESDD kelima unit sampel di lokasi itu. Setelah harga rata-rata ESDD pada suatu daerah dihitung, dan jarak daerah itu dari pantai diukur, maka diperoleh nilai ESDD untuk berbagai jarak isolator dari pantai. Hasilnya adalah seperti ditunjukkan pada Tabel 1 .

Tabel 1. Hasil pengukuran ESDD di pantai timur

\begin{tabular}{|c|c|c|c|}
\hline $\begin{array}{c}\text { Jarak } \\
(\mathbf{k m})\end{array}$ & $\begin{array}{c}\text { ESDD } \\
\left(\mathbf{m g} / \mathrm{cm}^{2}\right)\end{array}$ & $\begin{array}{c}\text { Jarak } \\
(\mathbf{k m})\end{array}$ & $\begin{array}{c}\text { ESDD } \\
\left(\mathrm{mg} / \mathrm{cm}^{2}\right)\end{array}$ \\
\hline 1,0 & 0,01820 & 35,0 & 0,01090 \\
\hline 2,0 & 0,02340 & 37,0 & 0,01053 \\
\hline 4,0 & 0,01549 & 40,0 & 0,00466 \\
\hline 4,5 & 0,01310 & 42,5 & 0,00682 \\
\hline 7,0 & 0,00650 & 44,0 & 0,00647 \\
\hline 11,0 & 0,01510 & 45,0 & 0,00400 \\
\hline 33,0 & 0,00423 & 77,5 & 0,00550 \\
\hline
\end{tabular}
Sumatera Utara Umur Isolator 11 Dan 12 Tahun

Sebaran data dan kurva regresi yang diperoleh ditunjukkan pada Gambar 3. Terlihat ESDD semakin kecil jika isolator semakin jauh dari pantai. ESDD turun $\pm 50 \%$ setelah jarak isolator dari pantai mencapai kurang lebih $40 \mathrm{~km}$. Pada jarak di antara 40 - $80 \mathrm{~km}$ dari pantai, ESDD hampir konstan. Artinya, kontribusi garam yang dibawa angin laut untuk mencemari isolator tidak begitu besar lagi. 


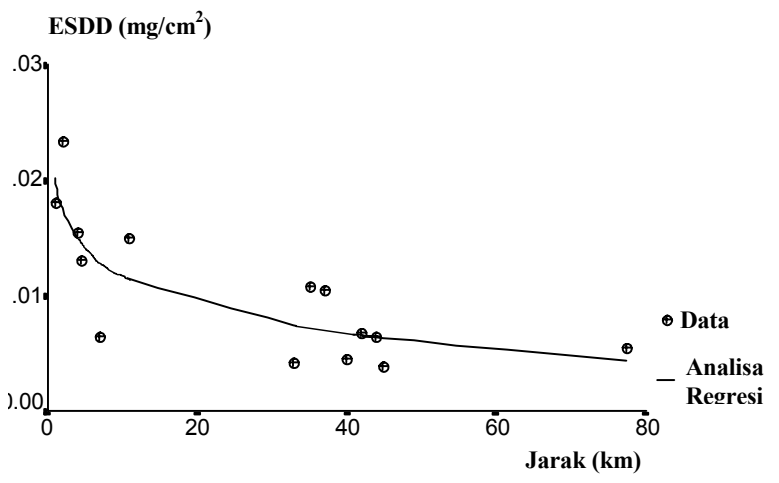

Gambar 3. ESDD Vs Jarak Isolator Dari Pantai Di Kawasan Pantai Timur Sumatera Utara

Menurut SPLN 10-3B, 1993, jika ESDD berkisar antara $0,03 \mathrm{~s} / \mathrm{d} 0,06 \mathrm{mg} / \mathrm{cm}^{2}$ maka intensitas polusi dikategorikan ringan [10]. Hasil pengukuran ESDD tertinggi adalah 0,0234 , dengan demikian tingkat intensitas polusi isolator di Pantai Timur Sumatera Utara masih dalam kategori ringan.

Hubungan ESDD dengan jarak isolator dari pantai di Sumatera Utara Bagian Timur, dapat didekati dengan persamaan di bawah ini:

$\mathrm{ESDD}=0,0204-0,00356 \mathrm{x} \ln ($ Jarak $)$

\section{KESIMPULAN DAN SARAN}

Kesimpulan yang diperoleh dari penelitian ini adalah:

1. Tingkat intensitas polusi isolator di pantai timur Sumatera Utara termasuk dalam kategori ringan.

2. Intensitas polusi isolator dapat dinyatakan berkurang secara logaritmik jika isolator semakin jauh dari pantai.

3. Dampak angin laut terhadap intensitas polusi sangat nyata hanya pada daerah-daerah yang dekat ke pantai.

4. Intensitas polusi isolator turun $\pm 50 \%$ setelah jarak isolator dari pantai mencapai kurang lebih $40 \mathrm{~km}$.

5. Pada jarak di antara 40-80 km dari pantai, intensitas polusi isolator hampir konstan. Artinya, kontribusi garam yang dibawa angin laut untuk mencemari isolator tidak begitu besar lagi.

Jika sumber utama polutan adalah penguapan air laut, maka ada dugaan bahwa ESDD di kawasan Pantai Timur berbeda dengan ESDD di kawasan Pantai
Barat, karena baik luas laut yang berhadapan dengan kedua kawasan tersebut maupun kecepatan angin laut pada kedua kawasan itu mempunyai sifat yang berbeda. Oleh karena itu masih perlu diadakan penelitian tingkat intensitas polusi isolator di Pantai Barat Sumatera Utara.

\section{DAFTAR PUSTAKA}

[1] Vosloo W.L., Holtzhausen J.P., "Insulator Pollution and Wetting Processes at a Severe Coastal Site”, XIIIth International on High Voltage Engineering, Netherlands, Rotterdam 2003

[2] P. S. Ghosh and N.Chatterjee, "Polluted Insulator Flashover Model for AC voltage", IEEE Trans. on Dielectrics and Electrical Insulation, Vol. 2, 1995, pp.128-136

[3] P. S. Ghosh and N.Chatterjee, "Arc Propagation Over Electrolytic Surface Under Power Frequency Voltage", IEEE Trans. On Dielectrics and Electrical Insulation, Vol.3, No. 4, August 1996, pp. 529-536

[4] CIGRE Working Group 33-04, "The measurement of site pollution severity and its application to insulator dimensioning for a.c. systems", Electra No. 64, 1979.

[5] IEC Report, "Guide for The Selection Of Insulator In Respect Of Polluted Conditions", Publication No. 815, 1986.

[6] G Besztercey, GG Karady, DL Ruff, "A novel method tomeasure the contamination level of insulators - spot contamination measurement", IEEE International symposium on electrical insulation, Arlington VA, USA, June 1998.

[7] CIGRE Taskforce 33-04-01, "Polluted Insulators: A Review of Current Knowledge", June 1999.

[8] G Besztercey, GG Karady, DL Ruff, "A novel method to measure the contamination level of insulators-spot contamination measurement", IEEE International symposium on electrical insulation, Arlington VA, USA, June 1998.

[9] Lambeth P.J.- Auxel H.- Verma M.P, "Methods Of Measuring The Severity Of Natural Pollution As It Affects HV Insulator Performance", Electra CIGRE No. 20, 1972, p. 37-52.

[10] SPLN 10-3B, "Tingkat Intensitas Polusi Sehubungan Dengan Pedoman Pemilihan Isolator", Perusahaan Umum Listrik Negara, 1993. 